\title{
Anita Desai's Fasting Feasting: A Picturesque Reflection of Male-Chauvinistic Indian Society
}

\author{
Mohammad Mozammel Haque ${ }^{1}$ \\ ${ }^{1}$ Lecturer, Department of English, Jazan University, KSA \\ Correspondence: Mohammad Mozammel Haque, Lecturer, Department of English, Jazan University, KSA.
}

Received: October 22, 2019

Accepted: November 1, 2019 Online Published: November 8, 2019

doi:10.5430/wjel.v10n1p1

URL: https://doi.org/10.5430/wjel.v10n1p1

\begin{abstract}
An attentive perusal of Anita Desai's Fasting Feasting shows that the novel is really a picturesque reflection of predicament, plight, pains and pangs done one the females in male-chauvinistic society of the then India. In other words, the novel reveals her struggle for female autonomy against the backdrop of the patriarchal cultural pattern prevailing in India. She has picturesquely shown how the women are deprived of what they deserve. Desai has used the characters of Uma and Anamika to delineate how women are bereft of human rights -social, political, familial, cultural, economic, academic etc. and used for sexual gratification and then discarded. How women are persecuted in the family as well as in the society by the husbands and father or mother-in-laws, ignored to be educated, bound to go for miscarriage or hysterectomy, not allowed to enjoy various tastes of life have also been depicted in the novel. That the 'new woman' is essentially a woman of awareness and consciousness of her low position in the family and society is discerned here. This paper, besides showing how the Indian women are indescribably and brutally persecuted in the family and society, sidelined and not allowed to be educated, suffer from father obsession and look for the typical father in her husband, also aims at describing how Anita Desai has struggled for the independence of women of her time.
\end{abstract}

Keywords: autonomy, chauvinism, deprivation, education, feminism, hysterectomy, persecution etc.

\section{Introduction}

The history of modern western feminism is divided into three waves and each is described as dealing with different aspects of the same feminist issues. The first wave refers to the movement of the $19^{\text {th }}$ through early $20^{\text {th }}$ centuries, which dealt mainly with suffrage, working conditions and educational rights for women. The second wave (1960s-1980s) dealt with the inequality of laws and the role of women in society. The third wave (late 1980s-early 2000s) is seen as both a continuation of the second wave and a response to the perceived failures.

Throughout the twentieth century there has been a study of a ubiquitous male control over every aspect of a woman's existence. Sarah Grimke observes:

Man has subjugated woman to his will, used her as a means of selfish gratification, to minister to his sexual pleasure, to be instrumental in promoting his comfort; but never has he desired to elevate her to that rank she was created to fill. (Bheda 39)

Alice Jardine, a professor of Romance Languages and Literatures and of Studies of Women, Gender, and Sexuality at Harvard University, offers a definition of feminism. 'Feminism, she writes, is generally, understood as a movement from the point of view of, by and for women.' (Jardine 15)

Toril Mori defines 'feminism' as a political position, 'femaleness' as a matter of biology and 'feminity' as a set of culturally determined characteristics. 'The two words 'feminist' and 'feminism', says Toril Mori, are political labels supporting the aims of women's movements of the 1960s.' (Mori 204)

Simply 'feminism' means the adage which advocates for woman's complete equality with men in all spheres of life - political, social, legal, economic, familial, cultural, academic, etc. - and the feminist movement is an organized effort for achieving such an equality and rights for women. 'Charlotte Perkins Gilman was the first woman who stressed for the economic independence of women.' (Gilman 187)

Similarly Simone de Beauvoir raised her voice against the sexual oppression of the patriarchal society.' (Gupta 7) 
In our selected novel Fasting Feasting, the writer has delineated how the Indian Women are deprived of these fundamental rights in comparison with the men.

Fasting Feasting gives a faithful expression to the 'Long smothered wail of lacerated psyche and tells the harrowing tale of blunted human relationships.' (Pathak 98)

Desai remarks:

'There are those who can handle situations and those who can't. And my stories are generally about those who can't. They find themselves trapped in situations on which they have no control.' (Bheda, Indian Women Novelists in English 14)

\section{Women in the Eyes of World-Famous Philosophers and Literati}

To quote Virginia Wolf, 'Imaginatively she is completely insignificant, she pervades poetry from cover to cover; she is all but absent from history.' (SenGupta 1)

The great philosophers who have immensely contributed to the existing values of life have paradoxically treated woman as an object to be used by man:

She is God's second mistake, said Nietzsche. To Aristotle she is an inferior man. He again says that the female is female by virtue of certain lack of qualities. Machiavelli chooses to identify woman with fortune: fortune is a woman, and if you wish to master her, you must strike and beat her. Schopenhauer says woman is by nature meant to obey. The saying tota mulier in utero (woman is nothing but womb) was in vogue. Shakespeare too refers it as, Frailty thy name is woman and the same idea is mentioned in The Taming of the Shrew e.g., Thy husband is thy lord, thy keeper, thy head, thy sovereign.

(Gupta, The Novels of Anita Desai A Feminist Pesrpective 6)

In Indian Vedic age Manu, the law giver of Hindu Dharma Shastra, clearly assigns woman a subordinate position to man:

During childhood, a female must depend upon her father, during youth, upon her husband, her husband being dead, upon her sons; if she has no sons, upon the near kinsmen of her husband; in default, upon those of her father, if she has no parental kinsmen, upon the sovereign; a woman must never govern herself as she likes.

(Gupta, The Novels of Anita Desai A Feminist Perspective 6)

Thus all the definitions about women's conduct, behavior, and existence were given by men. These aphorisms of a few of the great philosophers indicate the status of women in male-chauvinistic society. The old conventional notions of male-dominated society were so rude, unbearable, suppressive, oppressive, depressive and unscrupulous that women's discourse takes a shape of movement. Their consciousness seeks to analyze and understand the material conditions through which gender has been constructed within specific languages and bodies of literature. And its result is that the strong wave of feminism in 1960s and 1970s took place for women's liberation.

The above stated pictures about women have been drawn by the expert artist Anita Desai in her famous novel Fasting Feasting. The picture appears before the readers in every single line.

The very beginning of the novel indicates how the girls were treated differently in a family. Mama and Papa treat Uma, their daughter, very differently than they treat Arun, their son. They expect her to have no other needs, desires, or priorities other than meeting their needs. It's as if they see their daughter as an extension of themselves and their will, rather than as her own person.

\section{Women Were Treated Differently}

The novel opens in the modern day with Uma, middle-aged and still unmarried, at home in India in the summer, taking orders from Mama and Papa. They are instructing her with great importance about how they wish to have their afternoon tea. This leads to them barking orders at her, very specifically, about how to do many different household chores at once. They anxiously debate with each other about how best to instruct Uma to prepare a box of care goods to send to Arun, who is attending University in America. They worry that he has a warm enough sweater, and enough tea. Uma grows very flustered trying to meet their growing and changing demands. Her parents show no concern or even awareness for how their way of ordering Uma around is making her feel.

Mama and Papa put a lot of thought into their package for Arun. Meanwhile, MamaPapa expect a lot from Uma, and their way of piling demands onto her shows that they give little thought to whether or not Uma can actually meet those demands. 
Uma struggles to remember a time when MamaPapa had 'separate existences'. She recalls that Mama and Papa have offered few memories of their childhoods before their young marriage. Mama's recollections focus on family and include remembering little transgressions, such as the women of her house sneaking sweets to their daughters and nieces, as sweets were only allowed to boys in her household. Papa's recollections focus on the struggles of his boyhood in poverty and his hard work to overcome those deprivations so that he could go to school and become a lawyer, such as studying under streetlamps late into the night.

Mama's recollections about sneaking the sweets betray the unequal treatment of girls and boys in her own family and the secret defiance of women against that inequality.

Uma remembers the only example of Mama having a separate life from Papa as being when Uma was young and Papa was still working as an attorney. Mama used to sneak off to play cards with the women in her neighborhood. Mama would laugh loudly at the card games with the other women and would show a coy, playful side to herself. When Papa would return from work, Mama would pretend that she had not left the house that day. It means, women were not allowed to go out to enjoy some time with their near and dear ones. If they were allowed, why they should enjoy their time secretly and surreptitiously?

\section{Women Aren't Allowed to Enjoy Market Food Items / Women Were Deprived of Enjoying the Taste of Life}

Once Papa declares that Mama and Uma need to get some exercise, so he takes them to the park. At the park, Uma is expected to walk with Mama, and the two walk slowly, Uma following Mama's pace, while Papa circles the park several times on his own. Uma hungrily smells roasted nuts and cooked gram, which is garbanzo bean flour, and watches interestedly at the crowd, while her mother criticizes passerby for their immodest dress or behavior.

'Mama gives an annoyed little snort and tells Uma they will continue their walk by themselves and not try to keep up with Papa. Sedately, they circle the park, keeping to a path between the railing and the canna beds and pretending not to notice the peanut and ice cream vendors thrusting their wares between the bars and calling to customers. Uma finds saliva gathering at the corners of her mouth at the smell of the spiced, roasted gram but decides to say nothing.' (Desai 12)

It seems that to look at the sweet items in the market is a great offense for the females. Mama and Uma are unlucky as they are females, and not males. It is prohibited for them to look at them let alone hoping to taste them. So, they pretended not to notice them. Such kind of pictures of the then society even defeats the condition of women during the Dark Age when the girls were graved alive.

When Papa, Mama and Uma were doing rounds in the park, the driver was waiting outside. After finishing rounds, Papa was in a hurry to go back home lest Mama and Uma should want something to eat. As Papa was saying boringly:

'Get in', he says impatiently, I've been waiting for you. So slow. So slow. Get in. Get in. Quick, now.'

'Uma, scrambling in after Mama, says, 'Oof, Papa, why are we hurrying?'

Once Papa gives the drivers orders all the way home. Then Uma again asks:

'Why are we hurrying? Uma asks again querulously.' (Desai, Fasting Feasting 13)

Uma shows a hunger, not just for the literal nuts and gram she smells in the park, but for the sensations, smells, and sights presented to her in the park. She wants to linger because she has gotten a taste for life outside the world of her family, and she's curious for more. But unfortunately Uma is deprived of the enjoyment as the society itself doesn't allow her.

That women were neglected in the then society is reflected here picturesquely. Mama and Uma are not allowed to enjoy the taste of roasted nuts and cooked gram as they are women. Papa walks around the park instead of allowing Mama and Uma walking along with him maybe thinking that if he walks along with the women, his prestige will be under questions.

In the modern day, Uma is invited to a coffee party thrown by Mrs. O'Henry, the Baptist missionary she admires. Mama and Papa say there is no good reason for Uma to go. 'Why? What's wrong?' Uma demands heatedly, 'Nothing is wrong,' Mama replies sourly, 'only I don't see the need for such parties. Mrs O'Henry invites you to a party, then you will have to invite her to a party-'(Desai, Fasting Feasting 115)

Mama says that Uma doesn't have to run after Mrs O'Henry. Then Uma bravely replies:

'Papa has retired - he doesn't have any work,' Uma flares up, 'and still you go to dinner parties and to the club. And I don’t go running after Mrs O'Henry—she invited me - you heard her.' (Desai, Fasting Feasting 116) 
'Stay home and do your work - that is best,' Mama opines with an air of piety.

'I do my work all the time, every day,' Uma cries tearfully. 'Why can't I go out sometimes? I never go anywhere. I want to go to Mrs O’Henry's party.' (Desai, Fasting Feasting 117)

How unscrupulous the society is! It seems that it is a great felony for a girl to go out of the 'four walls.'

Thus Uma's revolutionary zeal reminds us Desai's revolutionary zeal for women's autonomy.

\section{Third Pregnancy after two Daughters Is a Shame for Women}

Uma remembers when Mama became pregnant with Arun, and she recalls this as the only time she noticed a significant inharmoniousness between her parents' desires. Uma remembers the secrecy and shame surrounding news of her mother's pregnancy. The narrator indicates that the secrecy ensued because pregnancy is a sign of sex - particularly female sex, which is shameful. When Arun is conceived, Mama is older and the pregnancy is painful, and she wishes she could terminate it. But with just two daughters, Papa wants a son. So Mama feels she has no choice but to go through with it, however miserable it makes her health. It seems that third time pregnancy is a shame for women if she already has got two daughters, and it is the only woman who enjoys sex, not the man. How gentle, polite and scrupulous the society is!

\section{Boys Are the Future-Lamps of a Family}

Though the pregnancy was painful for Mama as she was a bit older, but she has to bear it as Papa needs a son 'who will hold the lamp of the family in future which a girl cannot, or a girl is not strong or fit enough to hold that 'proud lamp'. How sarcastic, petrifying, horrible the situation for the women was at that time! Papa is proud when the boy is born, and Mama appears to welcome the son and recover her state of harmony with Papa. As the narrator says:

'Mama was frantic to have it (pregnancy) terminated. She had never been more ill, and would go through hellfire, she wept, just to stop the nausea that tormented her. But Papa set his jaws. They had two daughters, yes, quite grown-up as anyone could see, but there was no son. Would any man give up the chance of a son? The pregnancy had to be accepted.' (Desai, Fasting Feasting 16)

\section{A Boy, a Cause and Source of Elation in a Family}

When the boy Arun was born in the hospital, happiness knew no bounds in the family. Papa was springing in elation while going home with the news:

'Arriving home, however, he sprang out of the car, raced into the house and shouted the news to whoever was there to hear. Servants, elderly relatives, all gathered at the door, and then saw the most astounding sight of their lives- Papa, in his elation, leaping over three chairs in the hall, one after the other, like a boy playing leaf-frog, his arms flung up in the air and his hair flying. 'A boy!' he screamed, 'a bo-oy! Arun, Arun at last! It turned out that when a second daughter had been born, the name Arun had already been chosen in anticipation of a son. It had to be changed, in disappointment, to Aruna.' (Desai, Fasting Feasting 17)

How petrifying, how painful, how insulting, how grief-stricken, how mournful, how heart-rending the situation of the women was at the time when the novelist wrote the novel! From the above stated depiction of the narrator, it seems that women were not humans, rather they were burden for the family. Before Arun, two other children came to the same family, but MamaPapa didn't spring in ecstasy and euphoria at that time as they were not 'lucky' boys.

Extra, attentive and cautious care is taken of the new born baby boy when he is brought home. Mother is now advising Uma about how to fold nappies, prepare milk, take a 'boy' on lap etc. The narrator is observed to narrate:

'When Mama came home, weak, exhausted, and short-tempered, she tried to teach Uma the correct way of folding nappies, of preparing watered milk, of rocking the screaming infant to sleep when he was covered with prickly heat as with a burn. Uma, unfortunately, was her clumsy, undependable self, dropping and breaking things, frightenedly pulling away from her much too small, too precious, and too fragile brother.' (Desai, Fasting Feasting 18)

So, it also indicates the women who can bear a baby boy have great status in the society. The status in society depends on giving birth either to a baby boy or a baby girl.

The care that MamaPapa have for Arun is unequal to the care they put on their daughters, showing how they treat daughters as second-class children.

\section{Taking Care of a 'Boy' Is More Important than Going to School}

When Arun was brought home from hospital, Uma was appointed as a 'female servant' in the house to take special care of the new-born baby as it was a 'fortunate' boy. Once Uma says to her mother that she has to do her homework, then 
Mama answered tartly:

'I have to go and do my homework,' she told her mother. 'I've got to get my sums done and then write the composition' 'Leave all that,' Mama snapped at her.

'Uma had received such directions from Mama before; Mama had never taken seriously the need to do any schoolwork, not having gone to school herself. 'We used to have a tutor,' she said airily when the girls asked her how it was possible that she had not gone to school. He used to come to teach us - a little singing — a little - hmm' she became vague. We used to run away and hide from him, she admitted, with a giggle. So Uma tried to explain that if she did not get her homework done, she would be sent to Mother Agnes with a note.

'But we are not sending you to Mother Agnes_ - or to school—again,' Mama said.

'We are not sending you back to school, Uma. You are staying at home to help with Arun.' (Desai, Fasting Feasting 18)

Uma is interested in everything she studies, but she gets failing grades in every subject. She loves the western Christian religious atmosphere of the convent school, delighting in the religious education, the music, and looks up to the nuns - who are for the most part American and British. The nuns focus on proselytizing, but Uma seems neither aware nor bothered by this. Her grades are failing worse than ever when Arun is born, and when the nuns start sending notes home describing her bad scores, Mama tells Uma that there is no point in going to school any longer. Uma refuses to let Mama soothe her shaking hands when Mama tells her that she must prepare herself for marriage, and that in the meantime it is her job to stay home with Arun. Mama says this as if the society they live in doesn't allow the girls to be the member of the literati.

Uma used to reach school earlier than others, and also wanted to stay there for a long time: 'Uma was at school before any other child, and every day she searched for an excuse to stay on. School was not open long enough. There were the wretched weekends when she was plucked back into the trivialities of her home, which seemed a denial, a negation of life as it ought to be, somber and splendid, and then the endless summer vacation when the heat reduced even that pointless existence to further vacuity. She prickled with impatience for the fifteenth of July when school would re-open and a new term begins.' (Desai, Fasting Feasting 21)

It seems that house was like a prison for her where she didn't want to stay for long time.

When Mama comes to know that Uma has failed in almost all subjects, she says: 'You know you failed your exams again. You're not being moved up. What's the use of going back to school? Stay at home and look after your baby brother.'

'What is the use of going to school if you keep ailing, Uma? She is in a reasonable tone. You will be happier at home. You won't need to do any lessons. You are a big girl now. We are trying to arrange marriage for you.' (Desai, Fasting Feasting 16)

My question to Mama, would Uma fail if she was given at least some time to study in the house? Actually, it is not mother who stops Uma going to school, rather it is the society that does not allow Uma to go to school.

The idea of education for the girls is utterly defeated here in the hands of family needs that must be met only by the girls in a family.

\section{Education Is Ignored to Women}

Everyone's favorite cousin, the gracious, beautiful and intelligent Anamika, wins a scholarship to Oxford, but her parents, Lila Aunty and Bakul Uncle, do not consider allowing her to go. Lila Aunty and Bakul Uncle are none but the representatives of the society Anamika lived in where the girls, even being an outstanding student and winning a scholarship in a world-famous University, are not allowed to get access in the galaxy of higher education. The narrator ironizes saying:

'To Oxford, where only the most favoured and privileged 'sons' could ever hope to go!'

'Naturally her parents would not countenance her actually going abroad to study - just when she was of an age to marry-everyone understood that, and agreed, and so the letter of acceptance from Oxford was locked in a steel cupboard in their flat on Marie Drive in Bombay, and whenever visitors came, it would be taken out and shown around with pride.' (Desai, Fasting Feasting 69, 70)

Anamika could win the scholarship of Oxford but she was not allowed to go there to study, but with this win the family took pride and regarded the scholarship as a quality which will equalize her with the status of her would-be husband. The family took it as a good chance to find a good husband showing this 'family prize'. 
'The scholarship was one of the qualifications they were able to offer when they started searching for a husband for her, and it was what won her a husband who was considered an equal to this prize of the family.' (Desai, Fasting Feasting 70)

How selfish the society was! They used the scholarship to search for a better and qualified husband but they were not allowing Anamika to go to America for higher studies.

\section{Complain of a Father to Head Nun against His Daughter's Education}

Since Uma failed in every subject, Papa asked Mother Agnes, the head nun, not to allow Uma in the school any more. Once while everyone else is napping during a hot afternoon, Uma runs away from home. She hires a rickshaw to ride her to the convent school. There, she goes in search of Mother Agnes, the head nun, and falls at her feet, begging her to allow her to return to school, telling of her unhappiness at home with the baby. Mother Agnes embraces Uma, then tells her that she has done everything she can to convince Papa, and that now Uma should try to learn home keeping. Then Uma urges saying:

'But I will work very hard!' she yelled. 'I will pass next time. Please tell him, Mother—I will pass next time.' (Desai, Fasting Feasting 28)

Here, it may not be obvious whether Uma is really promising to study well or not, but it is clear to all that Uma is urging Mother Agnes to allow her in the school because she wants to get rid of the mental as well as physical torments she is bearing in the house.

'The more she yelled, the more dubious Mother looked. When Uma gabbled about the baby, not knowing how to bathe the baby, about being afraid to pin on his nappy, she began to grow impatient. 'Girls have to learn these things too, you know,' she said.'

'Uma was thunderstruck.' (Desai, Fasting Feasting 16)

The researcher cannot help laughing in over elation. This is because who I should blame? Mama, Papa, or Mother Agnes? Uma came to Mother Agnes in hope of getting something better, but in the long run Mother also advised Uma to take care of the baby instead of attending school. It is not Mama, Papa, or Mother Agnes, rather it is the society that is shaped in such a way that girls like Uma are not allowed to study as they are now in the age of marriage, and also as they have baby boys in the house to take care of which is really more important than going to school.

\section{Boys Need Proper Attention Which the Girls don't Need}

Mama showed Uma how to pour a little oil on her fingerprints and message it into the baby's limbs. And when Mama saw that Uma was successful, she turned away with a sigh of relief and was sure that the baby could be now left to his elder sister. But once Uma asked mother if she and Aruna could be taken care of by the ayah, then why not Arun. Mother protested saying:

'You know we can't leave the baby to the servant, she said severely. 'He needs proper attention.' When Uma pointed out that ayah had looked after her and Aruna as babies, Mama's expression made it clear it was quite a different matter now, and she repeated threateningly : 'Proper attention.' (Desai, Fasting Feasting 30)

Even when Mama left the baby with Uma or the ayah, to be bathed or dressed, she remained sharply vigilant of their performance. As for his meals, she watched over him like a dragon. When Papa returned from the office, he would demand to know how much his son had consumed and an answer had to be given.

How carefully the baby is being taken care of now! This was not done when Uma and Aruna were born. Alas! Uma and Aruna are undone as they are girls. How lucky Mr. Arun is!

\section{To Give Birth a baby Helps Mother Be Equal with the Father in Status}

In Desai's society, to be the mother of a baby boy is a matter of great honour and status. So it can unquestionably be stated that to be the mother of a baby girl is a matter of great dishonour and humiliation. Since Mama is now the mother of a son, she is allowed to wear a medal. Not only that, Mama now can accompany Papa to the clubs, to dinner party, and weddings, which was quite impossible for her before the birth of Arun 'the blessings for the family.' This idea is picturesquely reflected in the following lines:

'He had not only made her his wife, he had made her the mother of his son. What honour, what status! ----- she might have been wearing a medal.'

'Mama continued to deck herself in skills and jewelry and accompany Papa to the club, to dinner parties and weddings.' 
'It seemed to them that Mama sailed out with an added air of achievement. She had matched Papa's achievement, you could say, and they were now more equal than ever.' (Desai, Fasting Feasting 31)

Even as a little boy, Arun already knows that he has a more powerful place within the family than his older sister Uma.

\section{Girls Had no Right to Use Any Jewelry Items}

In the modern day, Mama and Papa have left home to attend a wedding. With few chances to be home alone, the middle-aged Uma relishes the opportunity. She is in her room, cheerfully going through her jewelry and her other trinkets, when Ayah, her family's servant, comes into her room and insists on brushing Uma's hair. It seems that girls are not permitted to wear or have any jewelry items. This is discerned in the following lines:

'She has looked through her card and her bangle collection. Hearing someone move about in the other room, she has quickly put these out of sight.' (Desai, Fasting Feasting 35)

\section{Girls Are Regarded as Unholy Creature}

That the plight of the then women was really long-smothered becomes clearer with the gradual advancement of the story. We once see the narrator stating that in the society Desai lived girls couldn't touch anything without washing hands or taking bath. Specially touching a baby boy was totally prohibited for a girl if she doesn't take bath: As the narrator says:

'Uma was not allowed to touch anything. 'Did you bathe when you came from school? Did you bathe after going to the toilet? No? Do you have your period now? Don't touch, child, don't touch?' (Desai, Fasting Feasting 41)

How scornfully Mama said this to Uma! It seems that if Uma were a boy, then taking bath isn't needed to touch a baby boy or anything.

\section{Churches' Door Seems to be Closed for the Girls}

There is no doubt that in the novel MamaPapa play role of the members of patriarchal society while Uma is the victim of that culture. Uma had long desire to visit Church but she was never allowed. But when she goes to chapel with Mira Masi, she feels very happy:

'and Uma felt she had been admitted to some sanctuary that had been previously closed to her. The nuns at St Mary's had allowed her as far as its portals - the assembly room, the hymn singing — but she had never been admitted into their chapel, and that was where she wanted to go, sensing this was the heart of their celebration.' (Desai, Fasting Feasting 43)

\section{Claustrophobic Atmosphere for the Girls}

When Ramu vai (nephew of Papa) came to their house, the bag he carried weighed him down at one arm. Seeing that, Uma rushes to take it from him. Ramu said:

'No, no,' he says, slapping her hand away. 'Ladies cannot carry bags for gents.'

How insulting the statement is! The whole society is framed in such a way that every male member of it doesn't mind humiliating any girl even if she is his near one or relative.

Moreover, Ramu vai and Uma expected to eat outside home but Papa didn't allow them to do that. The member of a claustrophobic society, Papa, is bound to say, 'No need to waste money by eating at Kwality's.' (Desai, Fasting Feasting 48)

Anyway, Ramu bhai, in spite of the unwillingness of MamaPapa, goes outside and takes Uma with him. That Uma was really in claustrophobic society is clearly understood when Ramu says to her that his main purpose to take her outside home is to let her enjoy her time the way she likes. As Ramu bhai says, 'I want you to enjoy yourself. Have another drink.'

After coming back home, Uma was going to tell Mama what she did and how she enjoyed her time outside home, then Mama said: 'Quiet, hussy! Not another word from you, you idiot child!' Mama's face glints like a knife in the dark, growing narrower and fiercer as it comes closer. 'You, you disgrace to the family — nothing but disgrace, ever'.

As Uma wanders by herself at the ashram, she finds happiness because she is free to meander and find a kind of freedom that she finds only in solitude. Uma's ability to find happiness just in her own company makes her different than most other characters in the novel. 
Desai is found to use irony and sarcasm to denounce the claustrophobic attitude of the society. Uma has gone to ashram with Mira Masi. MamaPapa thought that she will be back in a week. But when she was not back even in a month, they sent Ramu bhai to bring her back. We are dumfounded when we Uma asks Ramu:

'Back? Why?' she faltered, knitting her hands around the pillar. She had quite forgotten that she was expected to return.

'Because your MamaPapa thought you would be back in a week and you have been away for a month. ------ They were sure you'd been abducted by the priests.

'What's abducted?' Uma asked cautiously.

'Stolen. Kidnapped. Ravisehd!' he shouted. (Desai, Fasting Feasting 56)

Now, no need to think that MamaPapa has sent Ramu to take Uma back because they really are thinking that Uma might be abducted, stolen, kidnapped or ravished, rather they need Uma to do the household chores with which they are now tired as they have been doing these jobs for about a month.

\section{Girls Have no Right to Choose Her Spouse}

Anamika has many suitors, but her parents marry her off to a much older man because he 'matches' her in degrees and prestige. How unscrupulous and unprincipled the society is! They chose a husband for Anamika but his age was quite more than hers. They choose this old man 'because he had qualifications equal to hers; he too had degrees, had won medals and certificates, and it seemed clear he would be a match for her.'

Uma, Aruna and all the other girl cousins crowded around to see the match when he came, a bridegroom, to the wedding, and they fell back when they saw him, in dismay. He was so much older than Anamika, so grim-faced and conscious of his own superiority to everyone else present: those very degrees and medals had made him insufferably proud and kept everyone at a distance. The children saw that straight away: there would be no bridegroom jokes played at this wedding, no little gifts and bribes from him to them. In fact, he barely noticed them; he barely seemed to notice Anamika. The children saw that too- that she was marrying the one person who was totally impervious to Anamika's beauty and grace and distinction". (Desai, Fasting Feasting 70)

Thus a girl's virginity is less important to the parents than the medals and certificates of a man who is searching wife. The women really suffered from what is called dilemma of identity. Even the children could understand that the bridegroom himself was simply an old man who will not make any jokes with them. But they could say nothing as the society didn't allow them to.

\section{Girls/Wives Are Brutally Tortured/ Wives Suffer from Identity Crisis}

After marriage, the man pays no attention to Anamika, but rather appears to worship his own mother. Soon after their wedding, news floats to Uma's family that Anamika's husband and mother-in-law regularly beat her and that she is treated like a household servant. What a society it is! A wife is beaten by her husband and mother-in-law? How come! What a shame! Women were not treated as human beings? It seems that the wives or women didn't have any right to enter into the galaxy of those human beings who are happy in this world. The women who lived in this society suffered from dilemma of identity. She had to spend all the time in the kitchen, and had to eat at the last:

'Anamika had been beaten, Anamika was beaten regularly by her mother-in-law while her husband stood by and approved —or, at least, did not object. Anamika spent her entire time in the kitchen, cooking for his family which was large so that meals were eaten in shifts-first the men, then the children, finally the women. She herself ate the remains in the pots before scouring them. If the pots were not properly scoured, so they heard, her mother-in-law threw them on the ground and made her do them all over again.'

'When Anamika was not scrubbing or cooking, she was in her mother-in-law's room, either massaging that lady's feet or folding and tidying her clothes. She never went out of the house except to the temple with other women. Anamika had never once been out alone with her husband.' (Desai, Fasting Feasting 72)

Can it be thought that Anamika has any right to this family? Is she treated as a human being let alone being treated as a member of the family? How miserably she suffers from identity crisis in her own family! Her mother-in-law is also a woman but she thinks herself as the boss of the family and gives no importance to her as her son's wife. This is because, I think, this bossy mother-in-law couldn't also enjoy herself in the family when she was the wife of her mother -inlaw's son.

Anamika was always at the beck and call of her mother-in-law. Soon, Anamika miscarries due to a beating, becoming infertile. Uma hopes that her husband will send her back home to her parents, but Anamika doesn't return. 'Then the 
news came that Anamika had had to go to the hospital. She had had a miscarriage at home, it was said, after a beating. It was said she couldn't bear more children.'

How cruel and brutal the society is! The wives are beaten so ferociously and brutally that they miscarry.

'What will people say? What will they think?' (Desai, Fasting Feasting 72)

It is asked to Uma by her Mama. But I ask her, 'You also think about what people will say if Anamika is sent back from her husband's house to Lila Aunty and Bakul Uncle? What kind of actor or actress you are! Do people believe that people like you also think about the happiness of the girls of a family? If she is sent back because of her miscarriage, people will think about your prestige, but what about your social status if the people like Anamika's husband and her mother-in-law indescribably persecute the wife of their house?'

'Who cares what they say? Who cares what they think?' (Desai, Fasting Feasting 72)

It is boldly said by Aruna. This kind of brave statement from Aruna indicates that the deprivation for the girls of what they deserved has made them brave and revolutionary. Revolutionary zeal is observed when a society deprives somebody of what he / she deserves as crime is there where people are not given what they need.

'Don't talk like that, 'Mama scolded them. "I don't want to hear all these modern ideas. Is it what you learnt from the nuns at the convent?' She glared at Uma: Mother Agnes had made one of her periodic visits to persuade Mama to send Uma back to school and this always roused Mama's ire. Uma thought it better to withdraw. So then Mama glared at Aruna. 'All this convent education — what good does it do?' (Desai, Fasting Feasting 72)

How shamelessly a mother scolds her children because of nothing! She asks, 'What have you learned by going to the convent?' It means she makes the school responsible for the girls' 'misbehaviour'. Actually she couldn't tolerate her two children as they were girl. Thus, the two sisters suffer from the dilemma of identity in the family.

\section{Uma's Education Stopped}

Uma's education is now totally stopped for, maybe, two reasons: she is needed in the family, and now she is passing the age of marriage. MamaPapa now thinks that Uma shouldn't study after class VIII. As the narrator depicts:

'It was during the sad aftermath of Anamika's marriage that all the relatives received letters from Papa to say, 'Uma is still young but may be considered of marriageable age and we see no reason to continue her studies beyond class eight-; Papa had not informed them when Uma was withdrawn from school before that level'. (Desai, Fasting Feasting 75)

It seems that the women don't have any right to have higher education. Desai portrays this long-smothered plight of the then women just to criticize the society so that its eyes are opened and the society starts thinking women as a part of human beings and society; they also have right to know what they don't know, to go where they didn't go before. Desai seems to ask the society, 'Aren't the women created by God Who created the men? Don't the women take breath under the son where the men take?' If so, why shouldn't they have rights to enjoy what are enjoyed by men?

\section{MamaPapa in a Hurry to Drive Uma Away from Home}

Once a man eager to marry Uma is supposed to visit the house. Mama herself was beautifying Uma with aromatic cosmetic items. She was teaching her the answers of some general questions asked to a girl while the guardians of the groom come to see the girl. Mama taught her that she should say that she can prepare Samosas, barfi if Mrs Syal asks her. When Uma tried to say that she doesn't know how to prepare these things, Mama was threatening her like anything. That MamaPapa is really tired with the presence of Uma in the family and they want to get rid of her is understood from the following lines:

'Hold still. You have to look nice,' Mama said grimly.

'Now, if Mrs Syal asks if you made the samosas, you must say yes.'

'What if she asks me how? I won't know!' Uma cried

'Why don't you know? Didn't I tell you to go to the kitchen and learn these things? For so many years I have been telling you, and did you listen? No, you were at the convent, singing those Christian hymns. You were playing games with that Anglo-Indian teacher showing you how to wear skirts and jump around. Play, play, play, that is all you ever did. Will that help you now?' (Desai, Fasting Feasting 77)

How insulting and humiliating the comments of Mama to Uma are! It seems that Mama can take a sigh if she can drive away Uma with anybody in the country.

It won't be, I think, an overstatement to opine that Desai here criticizes the mean mentality of the then parents of the society. The novelist seems to ask, 'Have the girls been created only to do these household chores? Can't they 
contribute in the socio-economic development of a nation?' Actually, by this kind of denouncement, Desai demands the women's autonomy to the society.

MamaPapa respond to an ad in the newspaper for a family looking for a bride for their son. They meet the Goyal family, and the family makes an offer, asking that the dowry be given immediately to buy more property for their estate - which they promise to share between both families. Eager to marry Uma off, MamaPapa agree, and give the dowry. But a few weeks later, they receive word from the Goyal family that their son has decided to pursue his education instead. The dowry cannot be returned, for it has already been spent.

MamaPapa make a last effort at marrying Uma off. The old man from the newspaper ad accepts the offer, but when he arrives for the wedding, Uma is horrified to find that the man is old, fat, and shows no interest in her.

Desai here criticizes the mean-mindedness of the parents that in the society there was a malpractice and objectionable practice as well. The parents finally found a suitor who was not so young and was married before. How sarcastically Desai disparages the objectionable practice of marriage in the then society! She thus desires to bring out the women from the galaxy of male chauvinistic society. 'The man who finally approved of it and considered it good enough for him was not so young; he was married before.' (Desai, Fasting Feasting 89)

\section{A Mismatched Marriage Is Arranged for Uma}

When the 'old' man looked at Uma, he didn't show any interest. As the narrator says:

'He looked at Uma glumly and without much interest. What he saw did not seem to make him change his attitude.'

'The man looked as old to her as Papa, nearly, and was grossly overweight too, while his face was pockmarked.'

The 'old' man showed hardly any interest to Uma because this was his second marriage. He was an 'experienced' person. The feelings he had in his heart have already been given to his first wife. Since this is his second marriage, no change is seen in his appearance when he meets Uma.

But what about Uma? This is her first marriage. Can she tolerate and imagine that her would-be husband won't have any feelings to her at the first sight?

During the ceremony, the groom indifferently asks the priest to cut the ceremony short. 'Finally the sullen bridegroom broke in and said curtly to the priest, 'Cut it short, will you - that's enough now. The priest looked offended, Uma was mortified. If he could not even tolerate the wedding ceremony, how would he tolerate their marriage?' (Desai, Fasting Feasting 92)

Once at her new home, the husband leaves immediately, telling Uma that he has to work in Meerut. The women don't speak to Uma, but bark directions to her about cooking and chores. One day, Papa arrives, raging at the family, telling Uma that the husband has another wife and family in Meerut, and needed the dowry to save his business. Upon returning home, Aruna asks Uma if her husband touched her, and Uma says no, but privately wonders about the experiences she could've had. MamaPapa give up on marrying Uma, and Uma feels like she has lost all her value to her parents and family.

Uma is lonely, not because she pines for a husband, but because her community isolates her by failing to make a place for her in their world. It means, the society where she is born and brought up is not ready to give her a bit place to live in. The society seems to have a hope that Uma's mother will give birth to a son, and not a girt like Uma.

\section{Desai's Criticism on Dowry System Prevailing in the Society}

Desai here has directly attacked the practice of dowry system which is a curse on the women in the society. Harish (Uma's husband) has married the dowry not Uma as he has already a wife and four children. He has remarried only to save his pharmaceutical business with the money he gets from the bride's guardian. But what's Desai's reason behind portraying this sorrowful matter in this novel? She has attacked the society to remind the decision makers of it (society) that dowry is really a curse for the people who live here, and this system should be eradicated.

\section{Uma's Marriage Is Stopped / Cancelled}

Anyway, 'The marriage was somehow cancelled, annulled.'

'Having cost her parents two dowries, without a marriage to show in return, Uma was considered ill-fated by all and no more attempts were made to marry her off.' (Desai, Fasting Feasting 98)

How unscrupulous, corrupt, dodgy, unprincipled and scandalous the patriarchal society of Desai's India was! Mr. Harish din never think about the life of Uma, the helpless 'creature' of the time, rather money of 'dowry' was everything to him. 


\section{So Many Tutors Are Hired for Arun}

The novel flashes to an overview of Arun's childhood, which centers entirely on school. Papa allows him no rest: All year round, Arun has a series of tutors hired to drill words, rules, facts and formulas into his brain. This is the different and discriminating attitude that the society shows to the boys and girls. Previously, we have seen that Uma is not allowed to study after class eight; she fails in almost all the courses, but no tutor is brought for her. Anamika wins a scholarship to go and get admission in Oxford University, a world famous university in the world, but she is not allowed to go there for higher studies. This happens because they are girls. But for Arun, 'the pride for the family,' a series of tutors are hired. How unscrupulous, corrupt and crooked the society seems to be here! Desai criticizes these discriminating attitudes towards women as if she is longing for the women's freedom, and she wants them to come out of the four walls where they are confined.

'Tutors came in a regular sequence, an hour allotted to each, for tuition in math, in physics, in chemistry, in Hindi, in English composition - in practically every subject he had already dealt with during the hours at school.' (Desai, Fasting Feasting 122)

Uma and Aruna were raised only for marriage, not for education. They don't have any right to be educated. The only thing on which Papa gave emphasis was Arun's education. It seems that Arun's education is the 'pivot' around which everything in the family revolves.

When he reaches the end of his high school exams, Papa plunges him into applying for college, taking more tests, and applying for scholarships. When Arun's letter of acceptance to the University of Massachusetts finally arrives, Arun shows no excitement or relief, only exhaustion. Uma packs his bags while his father rests and his mother cries in pride, but even as he departs, Arun shows no joy. Uma is saddened, wishing he would be happy so that at least someone would be happy, even if she cannot be.

MamaPapa dedicate all of their efforts into Arun's health and education, in contrast with their neglect of Uma in these areas.

When Anamika won the scholarship in the Oxford University, Bakul uncle and Lila Auntie were not so happy with the news let alone distributing sweets to their relatives. But now Arun has got scholarship to study abroad, and thus the joy knew no bounds with MamaPapa as they are sending sweets to the relatives and neighbours.

\section{Uma Is Scolded Now like Anything for Her Lack of Education}

Uma is writing to Arun on behalf of MamaPapa, and Papa criticizes Uma for her slow writing and her inability to keep up with grammatical directions. Now Papa is criticizing Uma for her slow hand-writing, but they have forgot that they didn't allow her to study after class eight. How self-contradictory the things are! Don't you know what brackets are? What did they teach you at the convent? How funny! How sarcastic!' (Desai, Fasting Feasting 127, 128)

Previously they didn't allow her to study after class eight. Even they didn't allow or give opportunity to study at home. For this, she failed in almost all subjects. Now they expect the best performance from Uma. They are threatening her now telling, "Why don't you know how to write fast, what are the brackets?" How unscrupulous and dodgy! Desai expresses what she cherished in her mind out of her desire for the women's independence.

Previously they denied for Uma to receive even basic education, but now reprimand her weaknesses.

\section{Uma Is Advised to Go for Hysterectomy}

Getting an offer of a job from Dr. Dutt, Uma was surprised. She says: 'Job'? gulped Uma, never having aspired so high in her life, and found the idea as novel as that of being launched into space'. (Desai, Fasting Feasting 145)

Dr. Dutt was frequently requesting MamaPapa saying: 'After all, it is at my own institute, in a women's dormitory, with other women. I can vouch for the conditions, they are perfectly decent, sir. You may come and inspect the dormitory, meet the nurses, see for yourself. Would you like to pay us a visit, Uma?'

Mama and Papa can't even admit to her why they deny Uma her own career, so they lie, keeping Uma from the only opportunity for a new life she is ever given. "If you have that problem, you must come to the hospital for tests. If you need the hysterectomy, it is better to get it done soon. There is no need to live like an invalid." (Desai, Fasting Feasting 147)

Why does Uma need the hysterectomy? What is the problem? Because her father failed to marry her off with a good and competent husband. Since she has no possibility to be married, she wants to remove her womb now. How sorrowful and grief-stricken the news is to us! The society has totally failed to marry Uma off. Desai disparages this inconsolable situation of Uma just to let the world know that the women in the world are not being paid with what they 
deserve. There is no place for Uma to live in the society. Thus, there is no need to live like an 'invalid.' How pathetic the story is! Desai is bound to use the word 'invalid' for Uma. Uma is now invalid in the society. It seems that it is better for her to die now. If Uma dies, the world will get relieved of a heavy burden. It is, I think, out of her yearning for the women's freedom that Desai describes this distressed condition of the $20^{\text {th }}$ century Uma.

\section{Anamika Is Burned Alive}

It is the middle of the night, and the electricity has faltered. Uma fetches Mali, their elderly groundskeeper, who emerges from his small shack and goes into town to fix it. Before his return, another figure is seen coming in the darkness: a man with a telegram. Just as the electricity comes on and Mali returns, they open the telegram. It states simply: 'Anamika is dead.' Soon after, they hear the full story: Anamika was found burned to death by kerosene, wearing only a cheap nylon sari, before dawn on the porch outside her in-laws home. Different versions of the story float around. The mother-in-law claims Anamika snuck out before the house awoke and lit herself on fire, while the neighbors say that the mother-in-law dragged Anamika out in the middle of the night, with help from the husband, and burned her alive. Anamika's parents say whatever happened was destiny.

How can the news of Anamika's premature death be borne with? How tyrannical and oppressive the mother-in-law and husband were! What was her offence was not clear. She was burned to death by kerosene. Should we believe and think that Anamika committed suicide? If she commits suicide, then what are the reasons behind? Desai has picturesquely portrayed what she observes with her own eyes to happen in the society she lives in. The story of Anamika's death tragically symbolizes the final loss of female freedom. This kind of fate is common for almost all the 'unlucky and unfortunate' wives of the so-called 'aristocratic' husbands. Desai's only aim to let us know these pathetic stories is to ask us sympathize with them and bring about 'procession' in favour of women's liberty. The Indian society is no less than what is called the Dark Age. The only difference is that during the Dark Age, girls were graved alive, and now they are burned alive. How shameful the situation is! (Desai, Fasting Feasting 154)

\section{Conclusion}

Everybody is more or less aware of the condition of women during Dark Age i.e. before the birth of Mohammad (PBUH) bin Abdullah. At that time it was a matter of great insult and mortification for a father and a mother if the mother bore a baby-girl. The parents of that age threw their baby-girls into the grave alive. What a shame it is for humanity! Now, the condition of women during $20^{\text {th }}$ century India is more pathetic as well as heart-rending than that of the historical Dark Age. How funny it seems that Uma's parents will feel relieved and relaxed if Uma is, somehow, married off. Furthermore, Anamika's parents and relatives don't allow her to go to Oxford for higher studies. Finally, she is burned alive. How grief-stricken the matter is! Desai observed these indescribable plights of the women of her time from a distant place and suffered from ache in her heart out of which she has written this novel. This novel is nothing but a message to the world that she is in favour of the emancipation and independence of the women in the world. Women should be given what they deserve.

\section{About the author}

Mr. Mohammad Mozammel Haque is one of the youngest literati of Bangladesh. He did his BA (hons) and MA in English Language and Literature from Islamic University, Kushtia, Bangladesh. He has been working as a lecturer in the department of English, Jazan University, KSA since December 2008 till date. Before that he worked as a lecturer under the department of English at Bangladesh Islami University, Dhaka. Recently the author has received an offer letter to pursue his PhD in English Literature (Feminist Literature) in University Putra Malaysia. He got around eight of his articles published in the national and international journals. Mr. Haque has authored a book titled 'An Easy Way to Get Chance in Varsity'. He has also translated TJ Fitikides's 'Common Mistakes in English' from English to Bengali. His area of research is feministic literature. He writes for those who find themselves trapped in situations on which they have no control (the second sex).

\section{References}

Bheda, P. D. (2005). Indian Women Novelists in English. New Delhi: Sarup \& Sons, 2005.

Desai, A. (2008). Fasting Feasting. Haryana: Random House India, 2008.

Gilman, C. P. (1970). Women and Economics: A Study of the Economic Relation between Man and Woman as a Factor in Social Evolution. New York: Harper and Row , 1970.

Gupta, R. K. (2013). The Novels of Anita Desai A Feminist Perspective. New Delhi: Atlantic Publishers and Distributors (P) Ltd, 2013.

Jardine, A. (1986). Gynesis: Configurations of Women and Modernity. Ithaca: Cornel University Press, 1986. 
Mori, T. (1985). Sexual / Textual Politics: Feminist Literary Theory. London: Methuan Publishers, 1985.

Pathak, R. S. (1996). Modern Indian Novel in English. Delhi: Creative Books, Nice Printing Press, 1996.

SenGupta, J. (2013). Feminist Perspectives in the Novels of Toni Morrison, Michele Roberts and Anita Desai. New Delhi: Atlantic Publishers \& Distributors (P) Ltd, 2013. 